821.163.41.09-1 Црњански М.

https://doi.org/10.18485/msc_pred.2018.7.ch8

\author{
Предраг ПЕТРОВИЋ \\ Универзитет у Београду \\ Филолошки факултет
}

\title{
АВАНГАРДНА ПОЕЗИЈА МИЛОША ЦРњАНСКОГ
}

Идентитет песничког субјекта прве збирке Милоша Црњанског Лирика Итаке (1919) успоставља се у сталној, експлицитној и имплицитној, комуникацији, идентификацији те, коначно, полемици са низом историјских личности и књижевних фигура: „са Христом, Мефистом и Дон Хуаном", како вели стих провокативне унутрашње риме у песми „Портре”, са Цезаром, Милошем и Марком, Дантеом, Хомером и Његошем, Душаном, Ахилом и Гаврилом Принципом. На своме лицу лирски субјект препознаје сенку ђавола у песми „Самоћа”: на мом се лицу све угаси / и ђаво се јави у једној гримаси / што се смеје и гади", али дискретно ће се поистоветити и са разапетом христоликом фигуром сред модерног града: „ја стојим распет сам на зиду / и месец ми благо пробада ребра”, у песми „На улици”. Богати алузивни распон, разуђени каталог реминисценција и провокативна интертекстуална мрежа у Лирици Итаке у дослуху је са оном наративном инстанцом читања и писања каква се успоставља у првом роману Милоша Црњанског Дневник о Чарнојевићу. Ова динамична херменеутика субјекта важна је за одређење поетике Милоша Црњанског према књижевној, културној и националној традицији, односно за разумевање песничке самосвести у критичном историјском тренутку на измаку и непосредно након Великог рата.

Повлашћену позицију, ипак, имају две фигуре које се јављају на оквирима збирке - Одисеј, чијим гласом проговара лирско ја у „Прологу”, и Дон Кихот, тачније донкихотовски стилизовани Бог у претпоследњој песми збирке, „Молитва”. Управо ова песма у којој се христолики песнички субјект обраћа донкихотовском Богу Оцу, можда најбоље указује на сложеност удвајања, укрштања гласова и претапања фигура, имагинарних 
и сакралних, у Лирици Итаке. Занимљиво је одмах приметити и смисаону позицију коју у збирци има ова песма. Иако је у коначној композицији она претпоследња, након ње следи „Епилог”, у рукописима Милоша Црњанског, на врху странице на којој је „Молитва” откуцана машином, ауторовом руком је записано: „Ово долази као завршетак.” „Епилог” је на крају књиге као завршни шамар јавном мњењу, глас упућен читаоцима и критичарима док је „Молитва” смисаоно окончање модификације лирског субјекта од хероја-луталице античког света до витеза-луталице који стоји на почетку модерног доба. То је пут од авангардно ресемантизоване, из митских и епских оквира у домен историје и политике изведене фигуре Одисеја до последњег, уморног витеза, Дон Кихота, којим се не толико пародијски колико нихилистички разрешава питање апсолута у Лирици Итаке.

Зашто се песничко ја најпре идентификује са Одисејем? За разлику од модерне, на почетку века, када се позиција песника доводила у везу са Орфејем, рецимо у Дисовој поезији, авангарди је ближи Одисеј, мада су оба античка јунака осенчена искуством боравка у доњем свету. Одисејевске алузије присутне су у кругу немачке експресионистичке поезије, поготово код Готфрида Бена у чијој се драмској игри Итака (1919) митски топоси супротстављају сликама ратног ужаса. Фигура Одисеја код Црњанског свакако се не може свести на могући експресионистички утицај. У контексту целине његовог књижевног опуса али и изгнаничког живота, лик ратника који узалудно трага за завичајем добија колосални значај - од романескне визије сеоба као српског националног удеса до индивидуалне трагедије јунака који стално жуде за просторима среће и неспутаности. На измаку друге и почетком треће деценије прошлог века узбудљив је и сусрет Џојсове наративне и Црњанскове песничке имагинације, обе инспирисане Хомеровим епом. У разговору са Френком Баџеном Џојс ће Одисеја назвати најпотпунијим књижевним ликом: „Безвремени Фауст није човек. Хамлет јесте људско биће, али он је само син. Одисеј је син Леартов, али је и отац Телемахов, муж Пенелопин, љубавник Калипсин, брат по оружју грчких ратника пред Тројом и краљ Итаке. Он је изложен многим искушењима, али својом мудрошћу и храброшћу успева да их превазиђе."2 Разлози који су Црњанског привукли Одисеју свакако су другачији, штавише могло би се говорити о томе како песнички субјект Лирике Итаке готово декларативно одустаје од улога сина, оца, мужа и љубавника, или их доживљава на изразито провокативан начин. У двадесетом веку Одисеј ће бити присутан не само у поезији Кавафија, Сефериса или Казанцакиса, наших песника Рада Драинца, Јована Христића и Ивана В. Лалића, његове

${ }^{1}$ Милош Црњански, Лирика Итаке, приредио Гојко Тешић, Драганић, Београд, 1994, стр. 251.

${ }^{2}$ Frank Budgen, James Joyce and the Making of Ulysses, Indiana University Press, Bloomington, 1960, p. 48. 
авантуре и лутања постаће прадигматични за одређење неких аспеката друштва и културе новијег доба. У једној од најутицајнијих филозофских књига прошлога столећа, Дијалектищи просветитељства (1947), Адорно и Хорхајмер ће у догодовштинама Хомеровог лукавог јунака видети алегорију о путу и успону просвећеног разума, односно инструменталног ума, који ће се завршити тоталном преваром маса и свеопштом манипулацијом коју системи политичке и економске моћи, путем масовне културе, врше над друштвом. „Орган јаства којим оно преживљава пустоловине јесте лукавост. Поморац Одисеј вара природна божанства као што цивилизовани путник вара дивљаке нудећи им стаклене драгуље за слонову кост." $"$ Ма како га схватили, лукавство свакако није био разлог да Одисеј постане иницијални „протагониста” збирке Милоша Црњанског, мада би се поводом Лирике Итаке могло говорити о лукавству песничког ума који изокреће и изневерава жанровске конвенције. Због таквих језичких преиначења поезији М. Црњанског близак је Одисеј виђен из Деридине, деконструктивистичке перспективе која у путовањима славног поморца види непредвидљивост самог читања, односно лутање сваке поруке која трага за својом стално измичућом Итаком. ${ }^{4}$ Поетички, али и политички, разлог због којег се определио да проговори одисејевским гласом, Црњански даје у књизи Итака и коментари (1959). У белешци уз „Пролог”, песми за коју вели да је била његов књижевни програм непосредно по окончању рата, аутор своју тадашњу поезију одређује као „родољубиву, политичку и анархичну” и потом записује: „Тројанске и микенске алузије у тим стиховима биле су хотимичне. Песник сматра, и данас, Oдисеју за највећу поему човечанства, а повратак из рата за најтужнији доживљај човека."5 Повратник из рата, односно са светскоисторијске позорнице, модерни Одисеј више није херој него војник и то бунтовни, револуционарни војник, јер „све су револуције у то време биле побуне војника”, објашњава Црњански ситуацију у поратној Европи, што се указује као важно за поетику али и, у рансијеровском смислу схваћену, политику књижевности Лирике Итаке која се не односи на некакво ангажовање књижевности у политичким борбама него на могућност, па и потребу, књижевности да се бави политиком остајући уметност. „Тај израз претпоставља постојање суштинске везе између политике као нарочитог облике колективне праксе и књижевности као утврђене праксе уметности писања.”6

\footnotetext{
${ }^{3}$ Max Horkheimer, Theodor Adorno, Dijalektika prosvetiteljstva, prev. Nadežda Puhovski, Veselin Masleša, Sarajevo, 1989, str. 60.

${ }^{4}$ Дерида: 1997.

${ }_{5}^{5}$ Милош Црњански, Лирика Итаке и коментари, Штампарија Макарије, Октоих, Београд, 2008, стр. 95-96.

${ }^{6}$ Рансијер 2008: 7. И након четрдесет година од објављивања Лирике Итаке Црњански се у коментарима живо сећа како је она „одјекнула као бомба” у Београду након Првог
} 
Из света мита и епа Одисеј је у Лирици Итаке изведен у домен политике и идеологије. Када на почетку „Пролога” авнгардни Одисеј, повратник из новог тројанског рата, себе идентификује речима: „Ја видех Троју и видех све", та спознаја свега обухвата и искуство рата и ужасавајућег хода историје, што драстично мења његов идентитет. Хомеров јунак се враћа на своје острво неокрњен ратничким искуством, као суштински исти онај човек који је две деценије раније напустио Итаку, да поново заузме место које му по праву припада: позицију мужа, оца и владара. „Одисеј је у суштини безбедан”, коментарише Набоков, „Он је попут здравог човека у здравом сну који ће се, ма шта се са њим догодило, пробудити." Це Целина архајског света, коју је једини од грчких јунака пред Тројом, видео митски Одисеј била је заокружени, смислом испуњени тоталитет или, како вели Лукач, „то је један хомогени свет, и раздвајање човека и света, Ја и Ти, не може нарушити његову једнородност." ${ }^{8}$ Оно све које је видео авангардни Одисеј није таква непроблематична целина. Рат је драстично изменио његов идентитет, што се види не само у бледилу његовог лица него понајпре у ироничном тону и потенцирању туге и као емотивног стања али и онтолошког и аксиолошког упоришта (,да туга од свега ослобођава”). Митски Одисеј вратио се на Итаку са̂м, али не и напуштен од богова и ьихове пажње. У Лирици самоћа обеспокојавајуће нараста, кулминирајући у „Молитви” где песничко ја управо Богу упућује стихове којима одређује своју безнадну овоземаљску позицију: „и са̂м, савим са̂м”. ${ }^{9}$

Нови Одисеј на Итаки неће да обнови стари, него да успостави нови поетички, политички и идеолошки поредак, заправо да изведе револуционарни обрт. ${ }^{10}$ Завичај који затиче више није дом, некада је био, али након

светског рата, али додаје и ово: „Међутим, језиво актуелне постале су тек у току овог прошлог рата, без икаквих песникових заслуга. У томе је била њихова тајанствена судбина" (Црњански 2008: 96). Наравно, Црњански мисли на Други светски рат, али ове речи би се без икаквих ограда могле изрећи и након ратова вођених крајем прошлог века на балканским просторима. Као ни један други наш песник, Црњански је у својим стиховима изразио то језиво и увек присутно (са)дејство историје и политике.

${ }^{7}$ Одисејеву позицију Набоков описује поредећи га са Дон Кихотом, као романескним репрезентом модерног, десакрализованог па тиме и небезбедног света: „У Одисеји, као што се сећате, пустолови имају моћне помагаче. У сценама прикривања или прерушавања само смо напола уплашени да Одисеј може неким погрешним потезом прерано да открије своју снагу, док у случају Дон Кихотеа страхујемо да би урођена или друга слабост сиротог витеза могла бити разглашена његовим безобзирним сапутницима и душманима" (Набоков 2008: 27).

8 Лукач 1990: 24.

${ }^{9}$ Фигура самотног Одисеја који је у олуји изгубио све другове, проговара у Дучићевој „Песми”, објављеној 1929. у Српском књижевном гласнику и потом уврштене међу „Вечерње песме”: „Изгубих у том немиру / Другове и све галије / Који је сат у свемиру? Дан или поноћ, шта ли је?”

${ }^{10}$ У „Манифесту експресионистичке школе” (1920) Винавер пише да је „експресионизам револуционаран”, што нема само књижевну него и политичку конотацију. Као и Црњан- 
повратка из ратног ужаса историје то више није. ${ }^{11}$ „Али дома за нас нема”, вели се у песми „Химна” која следи након „Пролога”. Још драстичније звуче стихови из песме „Вечити слуга”: „Отаџбина је прљава улица / а очинство прљава страст”. У поезији Милоша Црњанског зато ће након Лирике Итаке почети да фигурира друго острво - Суматра, као егзотични и утопијски контрапункт пијанци и блуду који влада на Итаки. ${ }^{12}$ Једини обрачун који је нововековном Одисеју дозвољен није више оружани него поетички, што значи и политички. Иронично назване „мало нове песме” компензација су убојитих стрела које Хомеров јунак одапиње на разуздане просце.

Поезија Црњанског била је, како је примето Зоран Мишић, „највиши уметнички израз послератне духовне климе разочарања и клонућа, безнадежног, нихилистичког непристајања на неподношљиве оквире грађанског морала.”'13 Стихови „Видовданских песама” нису довели у питање само артизам из периода модерне него су и драстично оспорили етичке вредности на којима је почивао национални и културни идентитет. Оба ова момента очигледна су у песми „Споменик Принципу” у којој се програмски негира читав Ракићев циклус „На Косову”, који је до данас остао парадигма аристократске визије прошлости и врхунског уметничког израза видовданске етике. ${ }^{14}$ У свега две строфе сажета је и распршена слика косовских оклопника, Симонидиних ископаних очију, Јефимијиног деспотског достојанства и видовданског завета:

ски, и Винавер има на уму бројне револуције и побуне које су у то доба беснеле Европом. Алузије на та дешавања присутне су у готово свим текстовима Громобрана Свемира.

${ }^{11}$ У једном интервјуу из 1966. године, након окончања вишедеценијског изгнанства, Црњански говори о плановима да напише роман Повратак о „немогућности повратка у прошлост, као најстрашнијем феномену јаве и сна код човека" (Miloš Crnjanski, Ispunio sam svoju sudbinu, priredio Zoran Avramović, BIGZ, Beograd, 1992, str. 119). Заправо, могуће је вратити се у простор, али не и у прошло време, због чега је онда и сам простор обесмишљен, односно испражњен од некадашњег смисла.

${ }^{12}$ Ондашња критика није имала никакву сумњу да је Итака из „Видовданских песама” алузија на тек створену заједничку јужнословенску државу: „Строг према прошлости, песник иде дотле да, у „Гротески”, као да [се] разрачунава са Видовданским храмом. Једнако строг је и према садашњости. Југославију он назива Итаком, где је пијанка и блуд, где као да неки незнани просци харче народни иметак. Његово схватање југословенског јединста је готово очајно” („Критика о Лирици Итаке [1919-1925], у: Црњански 1994: 166).

${ }^{13}$ Мишић 1983: 134.

${ }^{14}$ Половином педесетих година прошлога века Војислав Ђурић изрекао је познату оцену да са Ракићевом поезијом косовски еп добија свој коначни, транспоновани и дефинитивни уметнички облик (Војислав Ђурић, „Милан Ракић”, предговор у: Милан Ракић, Песме, Српска књижевна задруга, Београд, 1956). 
„Слави и Оклопницима нек умукне пој.

Деспотица свети нек нестане драж,

Гладан и крвав је народ мој.

А сјајна прошлост је лаж.

А ко нас воли нек воли камен голи.

Нек пољуби мржњу и мртве.

Ископане очи, вино што се точи, у славу Убиства и жртве.”

Ови стихови успоставили су један од највећих дисконтинуитета у српској поезији и култури, што је приметила већ оновремена критика која је у бунтовном патриотизму младог Црњанског видела не само израз језичке неписмености и примитивизма него и етичке и националне неосвешћености. ${ }^{15}$ Али и за генерацију модернистичких „песника културе” након Другог светског рата ово авангардно оспоравање националних вредности биће неприхватљиво, што је најочигледније у Антологији српског песништва Миодрага Павловића која, доследно инсистирајући на континуитету и културном памћењу, Црњанском додељује периферну позицију (заступљен је са свега две песме).

Како разумети ову авангардну поетички, али истовремено и политичку самосвест у раној поезији Милоша Црњанског? Треба одмах рећи да се према питању непосредног политичког ангажовања књижевности песник јасно одредио у „Објашњењу Суматре” (1920). Иако нескривено истиче своју идеолошку припадност у том тренутку, ипак, што је много важније, Црњански одбацује могућност да поезија буде потчињена, и тиме вулгаризована, неким социјалним (или социјалистичким) дужностима: „Већина нас, најновијих, иако се налазимо на политичкој левици, одбацује све корисне, популарне, хигијенске дужности, које поезији, код нас, људи без осећања за уметност, а препуни социолошког самољубља, тако често намећу. Социјализам, на пример, ми не бисмо ширили лирским песмама!" 16 Јасно је, дакле, да је у Лирици Итаке реч не о таквом стављању поезије у службу политике већ о успостављању новог односа деловања и моћи језика у књижевном и друштвеном простору, о новом систему идентификације и разумевања уметности писања. На нов начин

\footnotetext{
${ }^{15}$ Упечатљивије од тих критика је сећање Милоша Црњанског на дане када је након објављивања Лирике Итаке „оглашен за лепру, од стране критичара Српског књижевног гласника. Песник је зато пролазио улицама Београда омрзнут, као Арнаут кога терају из његовог фиса. Али је он, и тада, у знак пркоса, носио на глави бере баскијско. Испунио је своју судбину на улицама Београда" (Црњански 2008: 96).

${ }^{16}$ Црњански 2008: 223. Важна је у овом контексту и сатирична алегорија „О боговима”, из збирке Приче о мушком (1920), у којој се алудира на Октобарску револуцију и пародијски деконструише идеолошка утопија о новом свету.
} 
разрешавајући однос између система значења речи и система видљивости ствари Лирика Итаке заснива нову демократију писања која жели да учествује у вредносној и смисаоној прерасподели друштвених пракси и говорних чинова, традиције и актуелности, видљивог и невидљивог, говора и буке на књижевној и јавној сцени. Реч је о оној могућности, која никада тако радикално није отворена у српској култури, да „књижевност утиче на израду хоризонта видљивости, на начине дешифровања тог хоризонта и дијагнозе о томе какво је место појединца и заједнице у њему." ${ }^{17}$ Овај демократски потенцијал поезије Црњанског не проистиче, наравно, само из циничног оспоравања аристократске визије прошлости каква је доминирала у парнасовској поезији модерне и, спрам тога, величању позиције сиротињског пука на светскоисторијској сцени („Раји, рити, дижите косовски храм"). Поезија присваја способност да критички промишља национални идентитет, заснован на видовданској етици и косовском завету, али и да разобличава званичну уметничку артикулацију тог идентитета, у песми „Гротеска” где се декомпонује Мештровићева високопарна и еклектичка замисао видовданског храма. Језик поезије Милоша Црњанског успоставља нове стратегије легитимизације истине које почивају на разноликим поступцима ироније, цинизма, пародије, карневалских обрта и оксиморонских структура. Поетичка могућност да се „истина утврђује довођењем лажи до апсурда”"18 доследно је спроведена у „Видовданским песмама” које, знатно пре надреалиста, активирају субверзивне потенцијале хумора, и то првенствено црног хумора, што је најдрастичније у језивим сликама „Оде вешалима”. Доследно успостављен систем жанровских обрта не тиче се само деструкције књижевних конвенција него и читаве мреже односа књижевности и друштвене стварности.

Обрт лествице културних вредност надилази националне, историјске и идеолошке оквире отварајући и питање трансцендентног порекла смисла и могуће метафизичке утехе. Док је одисејевска позиција важна за успостављање политике књижевности у Лирици Итаке, за разрешење односа према апсолуту као кључна указује се фигура Дон Кихота. Он се у песми „Молитва” доводи у везу са најузвишенијим сакралним ликовима Бога Оца и Исуса Христа. Као и Одисејева и сенка Витеза Тужног Лица протеже се дуж целог опуса Милоша Црњанског. Његов први и изгубљени роман, писан уочи Првог светског рата, у исто време када и шпански филозоф Хосе Ортега и Гасет објављује своју знамениту књигу Размишиљања о Кихоту (1914), имао је индикативни наслов Син Дон Кихотов ${ }^{19}$ Након рата, у предговору за Ујевићев превод Флоберовог ро-

${ }^{17}$ Рансијер 2008: 31.

${ }^{18}$ Бахтин 1989: 69.

19 „Пре одласка у Беч, са Сушака, у јесен године 1913, предао сам рукопис свог романа уреднику Бранковог кола у Сремским Карловцима, романа који се звао Син Дон 
мана Новембар (1920) Црњански ће Дон Кихота назвати оцем модерног човека. Позиција поратног индивидуума одређена је беззавичајношћу која се претвара у препуштање путовањима, у жудњу за етеричним даљинама и космополитску тугу, еквиваленту романичарског светског бола, пред којом све људско губи смисао: „Цео свет је његов. Прошлост и даљина нестају у њему. И оно што је пре много столећа било - његово је. Бол његов везан је за све патње у свету; он завичаја нема више, и све га предели растужују својим суморним видицима. Осетивши путовање и море, он зна да ни закони, ни границе, ни растојања не могу да препрече пут суморној магли која се шири у свему што је људско. Рад, све струке, јава, живот, све то губи смисао и снагу пред једном тајанственом тугом, која је у природи, вечна и неизбежна. На крају је опет смрт, која се диже као грдна сенка једне лађе: О смрти, стари капетане, и овај крај већ је досадан...Води нас даље, свеједно да ли у рај или у пакао, дај нам само нешто непознато и ново." ${ }^{20}$ Као што су Бодлерови стихови које Црњански овде наводи, имали свој одјек у завршетку песме „Пролог”, тако је и поменути полазак на путовање морем близак „Поздраву”, последњој међу „Видовданским песмама”. ${ }^{21}$ Она је поздрав слободи, али, наравно, не оној насталој вољом историјских процеса него вољом самосвесног поетичког ума, слободи која расте из туге, односно из стихова који тугом од свега ослобађају. Позиционирана на крају првог циклуса збирке, ова песма је и својеврсни опроштај новог Одисеја од Итаке која више није завичај. Водиља песничком субјекту није више завичај него слобода која обећава просторе животне и песничке неспутаности, „ван закона среће и бола". То је и симболично одустајање од одисејевске и приближавање оној џојсовској позицији Уликса који одлази са Итаке и лутања наставља просторима велеграда у „Стиховима улица”, али претходно заснивајући свој идентитет не више у домену политике и идеологије већ љубави, телесности и еротике у песмама циклуса „Нове сенке”.

Туга која „од свега ослобађава”, вечна и неизбежна, конкретизује се у фигури Витеза Тужног Лица у „Молитви”. Док је Мигуел Унамуно

Кихотов. Уредник је мом брату, у Новом Саду, причао да му се роман јако допада и да ће га штампати у свом листу. После је дошао рат и не знам шта је са тим рукописом било" (Црњански 1992: 25).

${ }^{20}$ Црњански 1991: 275-276.

${ }^{21}$ „Склапајући неку његову књигу”, пише о Црњанском Борислав Радовић, „човек и нехотице помишља да се ни његова немирна душа, као ни Бодлерова, нигде није добро осећала. Било куда изван света: приближно тако би могло да гласи и његово гесло, у Дневнику о Чарнојевићу, у Ембахадама и где све не” (Борислав Радовић, „Помисао на Црњанског”, О песницима и о поезији, Глас српски, Бања Лука, 2001, 58). Црњански ће управо Бодлера, у есеју о Андрићевом Ex pontu, назвати претходником етериста: „Они су као ветар, без закона, без пута и бескрајно верни сами себи. Фанатици бола, путовања и наде у даљину” (Црњански 1991: 142). 
почетком прошлог века племениту луду која полази да оствари свој витешки идеал и поправи свет, доводио у везу са Исусом, односно Исусовом жртвом, ${ }^{22}$ у песми Милоша Црњанског Бог Отац је донкихотовски стилизован. Обраћајући се Богу, песнички субјект га назива погуреном сенком на дрвеној раги, „са лонцем разбијеним на глави, / и очима пуним ветрењача плави”. Сличан опис, али у другачијем смисаоном контексту, наћи ће се и у роману Дневник о Чарнојевићу. У Рајићевом сну, Чарнојевић се коцка у собици препуној огледала када се на вратима појављује чувени оперски певач Фјодор Шаљапин који се у годинама пред Велики рат прославио улогом Дон Кихота у опери Жила Маснеа: „На вратима се указа Шаљапин, на раги, сав крив у седлу, са грдном мотком у руци и са једним разбијеним лонцем на глави, зидови се тресли од песме његове." 23 Међутим, алузије на Дон Кихота су у Дневнику поетичке фигуре које упућују на разноврсна удвајања, претапања фикционалног и стварносног, те, коначно, наглашавају позицију читања и имагинације као могућег изласка или уточишта од историје. Рајићев имагинарни, прочитаним књигама посредовани двојник, Чарнојевић, близак је оном Фукоовом одређењу Дон Кихота као „дугог, мршавог графичког знака попут слова, као да управо излази из отворене књиге. Читаво његово биће јесте само језик, текст, одштампани листићи, већ преписивана прича. Сачињен од изукрштаних речи: то је рукопис који лута по свету међу сличним стварима." 24 У „Молитви” је, међутим, Дон Кихотово појављивање другачије. Песма је испевана на фону молитве „Оче наш” која у верзији М. Црњанског није једноставно пародирана него провокативно преведена из домена високо канонизованог текста у интимно обраћање сина Богу Оцу којим се не тражи спас или утеха, већ

22 Де Унамуно 1969. Бројни каснији тумачи налазили су у Сервантесовом роману реминисценције на хришћанске поруке, али углавном у пародијском и циничном кључу. Тако Набоков вели да у бројним епизодама постоје мистичне импликације успостављене тако да је „Дон Кихот мање пародија витеза луталице колико Исусовог брата” (Набоков 2008: 167). Отвореност Серватесовог романа за различита читања показује Владимир Тасић у есеју „Дон Кихотова бесмртност”. Књига „коју сви читају и коју сви пишу”, како је назвао Карлос Фуентес, има стотине књижевних, ликовних, музичких и филмских обрада/тумачења. У једном од новијих, научно-фантастичној причи Пола Андерсона „Кихот и ветрењаче", витез узима обличје тужног робота који нема јасно дефинисану функцију па зато лута светом специјализованих апарата (Види о томе: Тасић 2005)

${ }^{23}$ Милош Црњански, Дневник о Чарнојевићу, Свесловенска књижарница, Београд, 1921, стр. 83-84.

${ }^{24}$ Фуко 1971: 111. Алузије на Дон Кихота присутне су и у каснијим романима Милоша Црњанског. У Другој књизи Сеоба Павлу Исаковичу се живот често чини „као ветрењача на ветру" а у завршном поглављу приповеда се о јуришу неког јунака који пада мртав с коња пред ветрењачом. У Роману о Лондону Рјепнин живи у делу града који се зове Mill Hill (Брдо ветрењача), а визија света као позорнице на којој сви играмо своју улогу, којом почиње роман блиска је Дон Кихотовом поређењу живота и позоришне представе у XII поглављу другог дела Сервантесове књиге. 
се изражава разочарање у хришћанску визију спасења и милосрђа. Ова песма заправо до краја реализује циничну мисао Сервантесовог романа о човековој овоземаљској судбини. Парафразирајући или алудирајући на јеванђеоске поруке, као на пример у епизоди са сељацима који су кренули да се освете својим суседима, Дон Кихот Христове визије преводи у грубу и немилосрдну стварност тако да оне почињу да звуче наивно и неубедљиво. Тиме „вера у праведно управљање светом од стране неке више силе, теоријски изражена, постаје пародија, а практично спроведена, постаје лудост." ${ }^{25}$ У песми Црњанског Очеви атрибути преведени су у свет донкихотовских привиђења чиме се божија порука о љубави и праштању указује као узвишено узалудни и илузорни пројекат. Ма колико племените биле, хришћанске вредности вишеструко превазилазе људске могућности на овом свету, а једина извесност је смрт, без икакве наде у искупљење и смисао. Наглашена легитимизација песничког субјекта као сина који се обраћа Богу Оцу, болно му поверавајући да више никоме не може помоћи и да нема никакве моћи (,син твој је бољи него анђели / али никоме помоћи не може”; ,син твој нема више моћи, / да се у шталама на путу ноћи / ичем од смрти нада"), сугерише да би лирско ја могло бити са̂м Исус, што нихилистичком одрицању смисла даје још потреснији и трагичнији тон. Дискретнија идентификација усамљеног песничког субјекта са болно разапетом христоликом фигуром успостављена је у песмама „На улици” и „Ја, ти и сви савремени парови”. Међутим, директно помињање Исуса увек је иронично - у „Оди вешалима” цинично се оспорава његова месијанска улога: „Па кад Исус не спасе нас, / ваше ће руке старе”, док је у песми „Портре” аксиолошки деградиран јер стих дели са ликовима из драстично другачијих културних сфера: „са Христом, Мефистом и Дон Хуаном”. Овај низ завршава се „Молитвом” која активира смисаоне потенцијале далекосежне визије отворене први пут у Сервантесовом роману, визије коју, на почетку Првог светског рата, Ђерђ Лукач види у знаку божијег напуштања света. „Човек постаје усамљен и може наћи смисао и супстанцију једино у души која нигде не налази завичај, свет је одвојен од свог сидришта и у присутној оностраности бива жртвован свом иманентном бесмислу, а моћ постојећег - ојачана утопијским везама које су од сада деградиране на пуко постојање - израста до нечувене величине водећи бесомучну, на изглед бесциљну борбу против растућих сила, још неухватљивих и неспособних да се саме открију и продру у свет."26

\footnotetext{
${ }^{25}$ Милошевић 1978: 146.

${ }^{26}$ Лукач 1990: 85. На питање зашто је Бог крајње равнодушан према Дон Кихотовим патњама, Набоков цинично вели да је то због тога што је вероватно заузет негде другде, односно да је ,доведен у неприлику због, можемо да претпоставимо, безбожних активности његових професионалних следбеника у том добу справа за мучење” (Набоков 2008: 28).
} 
Иако се „Молитвом” не призива него нихилистички одриче могућност хришћанског спасења, ипак се може поставити питање има ли смисаног излаза и наде на некој другој страни. Осим лирске благости, предавања даљинама и окретања од културе ка природи, што је изразито у песми „Етеризам”, посвећеној „другу Иви Андрићу”, у Лирищи Итаке отвара се још једна, херменеутички изазовнија могућност спаса скривена у домену језика, метафоре, односно анаграмске поруке и својеврсног криптописма које жели да се искаже и ослободи, али не може да се домогне коначне милости уобличења. То је она могућност коју у поезији Црњанског открива Данило Киш читајући анаграмску, ,заумну” поруку, скривену метафоричку вредност уписану у завршној „ехо” строфи песме „Серената” - наслов Дантеове књиге о љубави Vita Nuova (Нови живот):

„Но само јабланови вити

и борови пусти поносити

Но само јабланови вити

и борови пусти поносити."

Уместо хришћанског ту је дискретно назначено ренесансно откупљење кроз љубав у дантеовској апотеози која следи након ратног пакла. То оптимистичко Vita Nuova ипак „не може да се изговори јасно и гласно у срцу пакла, па се понавља као да се ослушкује, као да у тој репетицији (која је требало да буде варијащија), у том одјеку, остаје сва њена неисказност: далек одјек смисла који прераста у слутњу; у музику."27 Док ће свеприсутност љубави бити избављење у путопису љубав у Тоскани, смисао који прераста у музику водиће Црњанског до поновног откривања завичаја као метафизичке утехе у поеми Ламент над Београдом.

\section{ИЗВОРИ И ЛИТЕРАТУРА}

Бахтин 1989: Mihail Bahtin, O romanu, prev. Aleksandar Badnjarević, Beograd: Nolit.

Дерида 1997: Žak Derida, Uliks gramofon, prev. Aleksandra Mančić, Beograd: Rad.

Де Унамуно 1969: Miguel de Unamuno, Život Don Quijota i Sancha : komentar Cervantesovog Quijota, prev. Andreja Jakuš, Zagreb: Demetra.

Киш 2003: Danilo Kiš, Skladište, Beograd: BIGZ.

Лукач 1990: Georg Lukacs, Teorija romana, prev. Kasim Prohić, Sarajevo: Veselin Masleša.

Милошевић 1978: Nikola Milošević, Antropološki eseji, Beograd: Nolit.

\footnotetext{
${ }^{27}$ Kiš 2003: 130 .
} 
Мишић 1983: Zoran Mišić, Antologija srpske poezije, Beograd: Nolit.

Набоков 2008: Vladimir Nabokov, Predavanja o Don Kihotu, prev. Veljko Nikitović, Beograd: NNK.

Рансијер 2008: Žak Ransijer, Politika književnosti, prev. Marko Drča, Novi Sad: Svetovi.

Тасић 2005: Владимир Тасић, Њушкачи јабука, Нови Сад: Светови.

Фуко 1971: Mišel Fuko, Rječi i stvari, prev. Nikola Kovač, Beograd: Nolit.

Црњански 1991: Милош Црњански, Есеји, Нови Сад: Књижевна заједница.

Црњански 1994: Милош Црњански, Лирика Итаке, приредио Гојко Тешић, Београд: Драганић.

Црњански 2008: Милош Црњански, Лирика Итаке и коментари, Београд: Октоих. 